\title{
The union between Maronitae and Rome (1182) as the context of relationships between the Franks and the Oriental Churches in the Crusader states in the $12^{\text {th }}$ century
}

The origin of the Crusader states in the territory of Asia caused an accumulation of new problems concerning co-existence among various groups of people. The groups included peoples from Europe and the Near East: the crusaders called Franks, Catholics and different groups of Oriental Christians, Muslims and Jews. This short report will try to explain how the crusaders and Maronitae could have adjusted to the agreement although the Franks who acknowledged the bishop of Rome as their spiritual leader but the problems with Maronitae were different. Firstly, this paper will illustrate the situation of the Crusader states and then analyze the relationships between the Franks and the Oriental Christians. Finally, it will attempt to explain the problems of the union between Latin Christians and Maronitae. The source of this investigation is the chronicle of Wilhelm de Tyre entitled Historia rerum in partibus transmarinis gestarum a tempore succesorum Mahumeth usque ad annum Domini MCLXXXIV. ${ }^{1}$

The crusaders did not create one state but transferred their authorities from Europe. Those officials were typical for the Middle Ages: king and his

\footnotetext{
${ }^{1}$ Historia rerum in partibus transmarinis gestarum a tempore succesorum Mahumeth usque ad annum Domini MCLXXXIV edita a venerabili Guillemo Tyrensi archiepiscopo, Paris 1855, pp. 209-892 (Patrologiae cursus completus. Series Latina, 201); Historia rerum in partibus transmarinis gestarum a tempore succesorum Mahumeth usque ad annum Domini MCLXXXIV edita a venerabili Guillemo Tyrensi archiepiscopo, [in:] Historiens occidentaux. Recueil des historiens des croisades, ed. by A. A. Graf de Beugnot \& Le Prévost, vol. 1-2, Paris 1844; A History of Deeds Done Beyond the Sea by William Archbishop of Tyre, tr. E. A. Babcock, A. C. Krey, New York 1943.
} 
princes, dukes, counts, earls, barons and knights. ${ }^{2}$ The Kingdom of Jerusalem was at the top of this feudal pyramid. The first king of Jerusalem was Baldwin de Boulogne (1100-1118), ${ }^{3}$ replacing his brother Gottfried, who had been "Advocatus Sancti Sepulchri." In 1182 King Baldwin IV reigned in the years 1174-1185. The next authorities subordinate to the king of Jerusalem were: the county of Edessa, installed by Boemund de Boulogne ${ }^{4}$ and the county of Tripoli, installed by Raymond de Saint-Gilles (1102-1105). ${ }^{5}$ There was also the Principality of Antioch. ${ }^{6}$ In this country the situation was very intricate because the first prince Boemund (1099-1111) ${ }^{7}$ acknowledged the power of the Emperor of Constantinople, especially from the year 1108 when Boemund had to apply the laws of Emperor Alex Komnen (1081-1118) in these lands and to enact the Melchite Patriarch of Antioch. But the next princes did not always agree to be under the Greek power and they accepted the rule of the kings of Jerusalem. But from time to time the emperors had to fight with the princes of Antioch, especially when the prince of Antioch was Reginald de Châtillon (1153-1160). ${ }^{8}$

In the lands of the Middle East, conquered by the armed crusaders, there were many groups of Oriental Christians. These included the Melchites, the Monophysites: Jacobites, Armenians, Copts and Maronites who confessed Monothelitism.

${ }^{2}$ J. Flori, Rycerze i rycerstwo w średniowieczu, przekł. E. Trojańska, Poznań 2003, pp. 67, 173-181; F. Kusiak, Rycerze średniowiecznej Europy łacińskiej, Warszawa 2002, pp. 195-209; A. Vauchez, Duchowość średniowiecza, przekł. H. Zaremska, Gdańsk 2004, pp. 120-122; S. Lloyd, Ruch krucjatowy 1096-1274, [in:] Historia krucjat, red. nauk. J. Riley-Smith, przekł. K. Pachniak, Warszawa 2000, pp. 55-60; R. Fossier, Ludzie średniowiecza, przekł. A. Czupa, Kraków 2009, pp. 287-288.

${ }^{3}$ The dates of the rule is taken from: J. E. Morby, Dynastie świata. Przewodnik chronologiczny i genealogiczny, przekł. M. Rusinek, Kraków 1995. More about Baldwin I: Fulcherii Carnotensis Historia Hierosolymitana. Ab Anno 1099 ad Annum usque 1127, Paris 1854, pp. 861-902 (Patrologiae cursus completus. Series Latina, 155); Genealogia Comitum Buloniensium, ed. L. C. Bethmann, Paris 1854, p. 464 (Patrologiae cursus completus. Series Latina, 155); B. M. Balard, Wyprawy krzyżowe i łaciński wschód XI-XIV, przekł. M. Witkowski, Warszawa 2005, pp. 109-111.

${ }^{4}$ The same, Laciński Wschód XI-XV wiek, przekł. W. Ceran, Kraków 2010, pp. 83-87,125-126.

${ }^{5}$ More about Raymond: Raimundi de Agiles canonici Podiensis Historia Francorum qui ceperunt Jerusalem, Paris 1854, pp. 591-668 (Patrologiae cursus completus. Series Latina, 155); M. Balon, Bohaterowie świętej wojny, Kraków 2008, pp. 113-198; P. Biziuk, Hattin 1187, Warszawa 2004, p. 17.

${ }^{6}$ M. Billings, Wyprawy krzyżowe, przeł. Z. Dalewski, Warszawa 2002, p. 61.

${ }^{7}$ Anonima dzieje pierwszej krucjaty albo Czyny Franków i pielgrzymów jerozolimskich, przetł., wstępem i objaśnieniami opatrzył K. Estreicher, Warszawa-Kraków 1984, pp. 3, 24-25; H. E. Mayer, Historia wypraw krzyżowych, przekł. T. Zatorski, Kraków 2008, p. 79.

${ }^{8}$ M. Balard, Eaciński Wschód..., pp. 83-98; S. Runciman, Dzieje wypraw krzyżowych, vol. 2: Królestwo Jerozolimskie i łaciński Wschód 1100-1187, przeł. J. Schwakopf, Katowice 2009, pp. 13-100; N. Hooper, M. Bennett, Atlas sztuki wojennej w średniowieczu 768-1487, przekł. K. Bażyńska-Chojnacka, P. Chojnacki, Warszawa-Gdańsk 2004, pp. 96-99. 
The Melchite Church was most popular. The name Melchite came from the Arabic word malik and Syriac malaka and it meant "King's adherents" because they were protected by the Byzantine emperors. They were loyal to the orthodoxy of the Ecumenical Council at Chalcedon in $451 .^{9}$ The majority of the Melchites dwelled in the Principality of Antioch, which was one of the five ancient patriarchies. In this territory the number of the Melchites was almost half a million people. ${ }^{10}$ In Jerusalem they were not so numerous but they had the holiest places like the Basilica of the Holy Sepulchre, the churches in Bethlehem, Nazareth and on Mount Tabor ${ }^{11}$ The relationships with the Franks were full of variety. On the one hand, the crusaders were very friendly to those who helped them fight against Muslims. It was Firuz from Antioch who opened the gate and the crusaders could seize the city. ${ }^{12}$ Sometimes the Franks married women from the Melchite Church. King Baldwin II of Le Bourg (1118-1131) wedded Morphia of Melitena, and their daughter was a member of the Melchite Church and she married Fulco (1131-1143), the next king of Jerusalem. ${ }^{13}$ The Franks honored clerks who were harmed by the Turks. For example, it concerned John IV (1088-1100), the patriarch of Antioch. ${ }^{14}$ But when he died the relationships with the Franks got worse because Arnulf of Rohes (1099), the Latin Patriarch of Jerusalem, expelled the Melchite clerks from churches, especially from the Church of the Holy Sepulchre. The situation improved from 1142 as the King of Jerusalem Baldwin III (1143-1163) and Emperor Manuel I (1143-1180) signed a declaration about the Melchites from the Kingdom of Jerusalem. ${ }^{15}$ However, the clergymen of the Melchite Church were concerned about the

${ }^{9}$ K. Kościelniak, "From Grecian to Arabic. The Contribution of the Melchite Church to Arabic Culture In the Early Middle Ages ( $7^{\text {th }}-11^{\text {th }}$ Centuries)," Analecta Cracoviensia 38-39 (2006-2007), p. 493; K. Kościelniak, Grecy i Arabowie. Historia Kościoła melkickiego (katolickiego) na ziemiach zdobytych przez muzulmanów (634-1516), Kraków 2004, pp. 27-29; E. Wipszycka, Kościót w świecie późnego antyku, Warszawa 1994, p. 248; E. Przekop, Wschodnie patriarchaty starożytne, Warszawa 1984, p. 179.

${ }^{10}$ M. Balard, Eaciński Wschód..., pp. 87-92, 142. G. Troupeau, Kościót i chrześcijanie na obszarze Wschodu muzutmańskiego, [in:] Historia chrześcijaństwa. Biskupi, mnisi i cesarze 610-1054, vol. 4, red. G. Dagron, P. Riché, A. Vauchez, tł. M. Żurowska, G. Majcher, A. Kuryś, J. M. Kłoczowski, M. Kurkowska, Warszawa 1999, pp. 325-342.

${ }^{11}$ J. Murphy-O'Connor, Przewodnik po Ziemi Świętej, przekł. M. Burdajewicz, Warszawa 1996, pp. 54-55, 193; 253-254; 333-334.

${ }_{12}$ Anonima dzieje pierwszej krucjaty..., pp. 8, 70-71.

${ }^{13}$ M. Balard, Eaciński Wschód..., pp. 125.

${ }^{14}$ E. Patlagean, Stosunki między Konstantynopolem i Rzymem od połowy XI do końca XII wieku, [in:] Ekspansja Kościoła rzymskiego 1054-1274, red. tomu A. Vauchez, Warszawa 2001, pp. 305 (Historia Chrześcijaństwa. Religia, Kultura, Polityka, 5).

${ }^{15}$ K. Kościelniak, Grecy i Arabowie. Historia Kościoła melkickiego ..., pp. 236-137; J. Nasrallah, R. Haddad, Histoire du mouvement lttéraire dans l'Église Melchite du Ve au XXe siécle. Contribution à l'étude de la littérature arabe chrétienne, part 3, vol. 1: 969-1250, Paris 1983 , p. 47. 
liturgy so much that they ordered to clean the altars and liturgical vessels after they had been touched by the Franks. ${ }^{16}$

There were also Oriental Churches that did not acknowledge the Council of Chalcedon held in 451. They believed that Jesus had two phýsis, divine and human, but he did not exist in two phýsis because the divine nature conquered his humanity. ${ }^{17}$ The emperors fought against the Monophysites and when the crusaders captured the Holy Land they hoped that the situation would improve. It was especially the heterodox Monophysites, called the Jacobites, after their founder Jacob Baradajos (490-578). They lived in villages. In Jerusalem they had the monastery of Saint Mary Magdalene. The Crusaders often enlisted them to their army as light cavalry because the Jacobites knew how to fight with the Turks. ${ }^{18}$

The Armenians, who were Monophysites, lived in the county of Edessa and in the Principality of Antioch. In Jerusalem they had the church of Saint Jacob. In 1141 and 1142 the crusaders wanted to unite with the Armenians but it did not happen. ${ }^{19}$ In Jerusalem they lived around the church of Saint Jacob ${ }^{20}$. One member of this Church was Mathew of Edessa. He was a historian and spoke well about the kings of Jerusalem, especially about Baldwin II whom he praised. The Armenians often collaborated with the Franks against the Byzantine emperor because the Principality of Antioch had same Armenian countries as neighbors. The ruler of one of these states Toros had an alliance with Reginald de Châtillon, Prince of Antioch. They both invaded the Byzantines lands, especially their expedition against Cyprus in 1156 is well known. ${ }^{21}$

The other Monophysite groups were the Georgians, the Copts and Ethiopians but they were not very numerous, apart from their clerks in the holy places and monasteries. ${ }^{22}$

The Maronites lived in the county of Tripoli and in the North of the Kingdom of Jerusalem. Their beginnings were associated with the activities of Emperor Heraclius (610-641), who wanted to unify the Orthodox with those who did not acknowledge the Council of Chalcedon or the Monophysites. He wanted to have one united religion to fight with the Arab enemies. This doctrine was called Monothelitism because they confirmed that Jesus had one will power and two natures. In 680, during the sixth ecumenical Council in Constantinople

${ }^{16}$ M. Angold, Czwarta krucjata, przeł. B. Spieralska, Warszawa 2006, pp. 40-60.

${ }^{17}$ W. H. C. Frend, The Rise of the Monophysite Movement, Cambridge 1972, pp. $16 \mathrm{ff}$.

${ }^{18}$ K. Kościelniak, Grecy i Arabowie. Historia Kościoła melkickiego..., pp. 39-41; M. Balard, Łaciński Wschód..., p. 125; J. Murphy-O’Connor, Przewodnik po Ziemi Świętej..., p. 59; G. Troupeau, Kościót i chrześcijanie na obszarze Wschodu muzułmańskiego..., pp. 345-366.

${ }^{19}$ M. Balard, Eaciński Wschód..., p. 126.

${ }^{20}$ J. Murphy-O'Connor, Przewodnik po Ziemi Świętej..., pp. 66-70.

${ }^{21}$ Historia rerum in partibus transmarinis gestarum ..., liber 17-18, pp. 700-720.

${ }^{22}$ M. Balard, Łaciński Wschód..., p. 126. 
this creed was acknowledged as false. ${ }^{23}$ But these beliefs were preserved in the monastery of Saint Maroon, which was in the province of Apamea. When the monastery was demolished by the Bedouins in the middle of the $8^{\text {th }}$ century, the clergymen moved to the mountains in Lebanon, where they gained new adherents. They were named Maronitae after the monastery of Saint Maroon. Their patriarch was a wandering monk without a patriarchate so he could hide himself from his enemies, such as Muslims and emperor's soldiers. ${ }^{24}$ The Maronites had their own liturgy. ${ }^{25}$ They were treated as heretics so they could not enter the Holy Sepulchre. ${ }^{26}$

We know about the union between the Franks and the Maronites from the chronicle of Wilhelm de Tyre Historia rerum in partibus transmarinis gestarum. Wilhelm is a very trustworthy author because he was an educated man who knew Latin, Greek and Arabic. He was the Archbishop of Tyre, which was near the place where the Maronites lived, and he could have been better informed. ${ }^{27}$ Besides Wilhelm was a friend of Emeric de Limoges (1140-1193), the Latin Patriarch of Antioch who signed the treaty with the Maronites. ${ }^{28}$ The chronicle of Wilhelm suggested the following: ${ }^{29}$ "Interea, dum regnum pace, ut praediximus, gauderet temporali, natio quaedam Syriorum, in Phoenice provincia circa juga Libani, juxta urbem Bibliensium habitans, plurimam circa sui statum passa est mutationem. Nam cum per annos pene quingentos cujusdam Maronis haeresiarchae errorem fuissent secuti, ita ut ab eo dicerentur Maronitae, et ab Ecclesia fidelium sequestrati, seorsum sacramenta conficerent sua, divina inspiratione ad cor redeuntes, languore deposito, ad patriarcham Antiochenum Aimericum, qui tertius Latinorum nunc eidem praeest Ecclesiae, accesserunt; et abjurato errore, quo diu periculose nimis detenti fuerant, ad unitatem Ecclesiae Catholicae reversi sunt, fidem orthodoxam suscipientes, parati Romanae Ecclesiae traditiones cum omni veneratione amplecti et observare. Erat autem hujus populi turba non modica, sed quasi quadraginta millium dicebatur excedere quantitatem, qui per Bibliensem, Botriensem et Tripolitanum episcopatus, juga Libani et montis devexa, ut praediximus, inhabitabant; erantque viri fortes et in armis strenui, nostris, in majoribus negotiis quae cum hostibus habebant frequentissime, valde utiles; unde et de eorum conversione ad fidei sinceritatem,

${ }^{23}$ G. Dagron, Kościól bizantyjski i chrześcijaństwo bizantyjskie między najazdami a ikonoklazmem (VII wiek-początek VIII wieku), [in:] Historia chrześcijaństwa. Biskupi, mnisi i cesarze..., pp. 45-47; S. Runciman, Teokracja Bizantyjska, przeł. M. Radożycka-Paoletti, Katowice 2008, pp. $75-76$.

${ }^{24} \mathrm{G}$. Troupeau, Kościót i chrześcijanie na obszarze Wschodu muzutmańskiego..., pp. 342-345.

${ }^{25}$ M. Hayek, Liturgie maronite, Tours 1964.

${ }^{26}$ J. Murphy-O'Connor, Przewodnik po Ziemi Świętej..., pp. 53-61.

${ }^{27}$ S. Runciman, Dzieje wypraw krzyżowych, t. 2: Królestwo Jerozolimskie ..., pp. 408-409.

${ }^{28}$ M. Balard, Laciński Wschód..., p. 126.

${ }^{29}$ Historia rerum in partibus transmarinis gestarum..., liber 20, caput 8, pp. 855D-856C. 
maxima nostris accessit laetitia. Maronis autem error et sequacium ejus, est et fuit, sicut et sexta synodo legitur, quae contra eos collecta esse dignoscitur et in qua damnationis sententiam pertulerunt; quod in Domino nostro Jesu Christo una tantum sit, et fuerit ab initio, et voluntas et operatio. Cui articulo ab orthodoxorum Ecclesia reprobato, multa alia perniciosa nimis, postquam a coetu fidelium segregati sunt, adjecerunt; super quibus omnibus ducti poenitudine, ad Ecclesiam, ut praediximus, redierunt Catholicam, una cum patriarcha suo et episcopis nonnullis, qui eos sicut prius in impietate praecesserant, ita ad veritatem redeuntibus, pium ducatum praestiterunt."

From this text we know that the union was signed when there was some peace between the crusaders and Saladin (1175-1193), ${ }^{30}$ i.e., between 1180 and 1182. The Maronites turned to Emeric, the Patriarch of Antioch, concerning their return to the one, right Ecclesia. Wilhelm wrote that Maronitae had been heretics for five hundred years. They were very numerous because their number was some forty thousand. They lived in the mountains. They did not have any cities but only villages between Byblos and Batrun. When Wilhelm wrote about the Maronites directly he hoped that they could join the crusaders' army. Baldwin IV (1174-1185) had the same idea. His teacher was Wilhelm de Tyre ${ }^{31}$ The Maronites rejected Monotheletism and recognized Pope Lucius III (1181-1185) $)^{32}$ and his successor as their spiritual head. This union was lasting and besides demolished Crusader countries by Muslims.

It was a very important union because the period of the crusaders and the Franks is considered as bloody and turbulent in the Middle East. Contemporary people think that there was no peace during the Crusades and that the Franks did not only disturb the Muslims but also the Oriental Christians. It is not completely true. There were a few exceptions because in the fragment of Wilhelm de Tyre's chronicle we can see that those Latin Christians were able to make arrangements with the Maronites. Contemporary researchers of the Maronites' history suppose that the crusaders' time was the golden era for their believers thanks to the union of $1182 .{ }^{33}$

The time when the Franks were in the Near East ended in 1291 when the Egyptian Mamelukes captured Acre and when they occupied the island of Ruad in 1302. Almost two centuries of the Latin presence in these territories caused new, very inquisitive processes.

\footnotetext{
${ }^{30}$ More about Saladin: S. Lane-Poole, Saladyn Wielki i upadek Jerozolimy, przekł. B. Tkaczow, Warszawa 2006, pp. 73-288.

${ }^{31}$ S. Runciman, Dzieje wypraw krzyżowych, t. 2: Królestwo Jerozolimskie ..., pp. 408-409.

${ }^{32}$ A. P. Bagliani, Kościót rzymski od I soboru laterańskiego do końca XII wieku, [in:] Historia chrześcijaństwa. Religia, kultura, polityka. Ekspansja Kościoła rzymskiego 1054-1274..., pp. 190-191.

${ }^{33}$ J. Riley-Smith, Odrodzenie i przetrwanie, [in:] Historia krucjat, red. J. Riley-Smith..., p. 408.
} 